IZA DP No. 4860

The (Hidden) Financial Flows of Terrorist and Organized Crime Organizations: A Literature Review and Some Preliminary Empirical Results

Friedrich Schneider

March 2010 


\title{
The (Hidden) Financial Flows of Terrorist and Organized Crime Organizations: A Literature Review and Some Preliminary Empirical Results
}

\author{
Friedrich Schneider \\ Johannes Kepler University of Linz \\ and IZA
}

Discussion Paper No. 4860

March 2010

\author{
IZA \\ P.O. Box 7240 \\ 53072 Bonn \\ Germany \\ Phone: +49-228-3894-0 \\ Fax: +49-228-3894-180 \\ E-mail: iza@iza.org
}

\begin{abstract}
Any opinions expressed here are those of the author(s) and not those of IZA. Research published in this series may include views on policy, but the institute itself takes no institutional policy positions.

The Institute for the Study of Labor (IZA) in Bonn is a local and virtual international research center and a place of communication between science, politics and business. IZA is an independent nonprofit organization supported by Deutsche Post Foundation. The center is associated with the University of Bonn and offers a stimulating research environment through its international network, workshops and conferences, data service, project support, research visits and doctoral program. IZA engages in (i) original and internationally competitive research in all fields of labor economics, (ii) development of policy concepts, and (iii) dissemination of research results and concepts to the interested public.
\end{abstract}

IZA Discussion Papers often represent preliminary work and are circulated to encourage discussion. Citation of such a paper should account for its provisional character. A revised version may be available directly from the author. 


\section{ABSTRACT \\ The (Hidden) Financial Flows of Terrorist and Organized Crime Organizations: A Literature Review and Some Preliminary Empirical Results ${ }^{*}$}

The financial means of international terror and organized crime organizations are analysed. First, some short remarks about the organization of international terror organizations are made. Second and in a much more detailed way a literature review is provided about the financing of terrorist and organized crime organizations, their sources and the various methods they use. Third, an attempt is made to estimate the financial means of terror organizations with the help of a latent estimation approach (MIMIC procedure). The figures show that Al Qaeda and other terror organizations have sufficient financial means. Fourth, some remarks are made about the negative effects of terror on the economy in highly developed countries and some strategies are presented to combat (the financing) of terrorism.

JEL Classification: K42, H56, O17

Keywords: financial flows of terrorist organizations, financial flows of organized crime, Hawala banking, money laundering, organized crime, terrorist organizations, kinds of terrorist financing

Corresponding author:

Friedrich Schneider

Department of Economics

Johannes Kepler University

Altenbergerst. 69

A-4040 Linz

Austria

E-mail: friedrich.schneider@jku.at 


\section{Introduction}

Until 2009, the development of the world economy and globalization made enormous gains in economic well-being possible, but this development has always contained risks, too. One of them is (transnational) terrorism and the global number of terrorist attacks, which rose from 208 in 2003 to ca. 864 in 2008 ${ }^{1}$. The terrorist attacks on September 11, 2001 are an example of how extreme critics of globalization and of the western type of civilization fight violently against its economic advantages. Among others this raises the following questions: (1) What forms of terrorism are there? (2) How is terrorism and organized crime financed, and what do we know about this financing? (3) Which economic implications do terrorism and the combating of terrorism have? In this paper question (1) and (3) will be very briefly answered, the main focus lies on providing a much more detailed answer on the financing of terrorism and organized crime - question (2).

\subsection{Transnational Islamistic Terrorism - The Example of Al-Qaeda ${ }^{2}$}

In the case of terrorism, national and transnational (usually religious fundamentalist) terrorism have to be distinguished (see also Sedgwick (2007)):

Transnational terrorism has three basic features:

(1) Almost unlimited operational range of religious terrorism (global theatre).

(2) Global support base, e.g. on the internet with spontaneously emerging local cells.

(3) Broad concept of the enemy without limitations - meaning there is no overarching goal (Islamist global domination) but 'only' a common enemy (usually the USA and / or the highly developed Western world).

A major goal of Al-Qaeda is to weaken Western civilization; to unleash a 'Global Jihad'. AlQaeda is 'only' a brand with an extremely shallow hierarchy. Instead of being an organization it is rather a 'virtual business corporation'; its slogan is that 'dying is more important than killing' and 'mass murder becomes a sacred act', meaning that there are no limits to the choice of means. There is no global strategy, apart from destroying Western civilization. Thus one should adjust to a long-term ideological conflict and resort to offensive (including military) approaches to Al-Qaeda.

\footnotetext{
${ }^{1}$ On the emergence of terrorism, its financing and consequences for the economy see: Schneider (2004), Freytag et.al. (2009), Lai (2007), Krueger and Malecková (2003), Li and Schaub (2004), as well as Schneider, Brück and Meierrieks (2010).

${ }^{2}$ Also see: Addison und Murshed (2005), Enders and Sandler (2002, 2006), Tavares (2004), Brück (2004) as well as Alexander and Alexander (2002).
} 


\subsection{The Terror Attack in Mumbai: A Case of Transnational Terrorism}

The international conglomerate of Islamist terrorism, which is most probably being steered by Al-Qaeda, once again struck in Mumbai in a terrible manner. The target was again chosen according to the following pattern:

1. A healthy and open democracy with a free press which guarantees that the news of a terrorist attack will immediately be spread worldwide.

2. A location that is globally known and at which many important economic, political and religious institutions can be found whose function can be severely hampered by terrorist attacks (tourism, stock exchange, economic life, religious institutions).

3. The possibility to cause maximum damage within a short time-frame with 15 to 20 terrorists and guaranteeing global attention.

Unfortunately, Mumbai fits this pattern in an excellent way. Additionally, the attacks should have lead to a destabilization of the entire region by furthering distrust between India and Pakistan, possibly causing high tensions and armed conflicts between the two countries.

The craft of international Islamist terrorism is a modern form of terrorism, a mixture of Jihad and cynical calculations, aiming at demolishing open democracies and the Western way of life through terrorist attacks. This form of terrorism develops in the mind of a handful of analyzers and is then implemented by a couple of well-trained terrorists who were probably continuously instructed by their 'mastermind'. Of course they were ready to put their lives on the line. Their own martyrdom is not the crowning finale, but the execution as such, and the assurance of gaining the world's attention. It is obvious that the war of Islamistic terror is wearing on, and that those Al-Qaeda (and other terrorist organizations), who have lasting political, logistic and financial support can always cause shock and awe on a global scale. This approach of world-wide terror attacks perpetrated in an unpredictable pattern is pursued with the intention of spreading a permanent feeling of a state-of-emergency, which leads to increased distrust between different countries, regions and power blocks and restrains the freedom, democracy and pluralism of the Western lifestyle. 
What can be done against this form of terrorism? ${ }^{3}$ A dialogue in the region and also between the cultures is surely indispensable, and mutual respect and tolerance can lead to gains for all parties involved. It is obvious that the terrorists would fall short of achieving one of their most critical aims, if India and Pakistan were to cooperate against terrorism instead of confronting each other. On the one hand, tolerance and understanding will not be enough to put an end to the terrorists' game. It will be crucial to reduce the breeding ground for terrorism in two ways: on the one hand, by reducing poverty and - even more importantly - providing people with a perspective. This would be a significant step forward for many people in India, Pakistan and other poor regions. On the other hand, a spiritual and religious confrontation with this kind of terrorism and its mastermind has to be undertaken in order to deprive it of its religious breeding ground.

In this line a detailed analysis of the finances of terrorist and of organized crime organizations is crucial to fight terrorism by reducing their financial possibilities, so that the basis of their operations is at least limited. Such an analysis is the main goal of this paper. Chapter 2 provides an extensive literature review at about the kinds of terrorist and organized crime financing. In chapter 3 an estimation of the amount of financial flows of Islamistic terrorist organization is undertaken. In chapter 4 some implications and damages of transnational terrorism are shortly presented, and finally in chapter 5 some policy conclusions are drawn.

\section{The Kinds of Terrorist and Organized Crime Financing: A Preliminary Literature Review}

The literature review is supposed to meet the two objectives: to widen the knowledge of this subject and the understanding of the main issues under debate and to focus on the literature closely related to the research topic. The body of literature on terrorist and organized crime financing, and their mechanisms is diverse and quite often very descriptive, hence here only some and important contributions are summarized, of course this selection is subjective, but I think most areas are covered.

\subsection{A Short History of the Terrorist Financing Issues}

The capacity of transnational organizations to generate world panic and cause intensive damage to a nation is an old and well known phenomenon. The anarchist movements at the end of the nineteenth century are a good example. For example, the late 1960s and 1970s

\footnotetext{
${ }^{3}$ See also: Tavares (2004), Indridason (2008), Gross et.al (2009) as well as Frey and Luechinger (2008).
} 
were characterized by the rise of secular separatist and mostly left-wing terrorist groups, and since the early 1980s the emergence of religiously motivated terrorism especially extreme Islamist movements dominated the terrorist scene. ${ }^{4}$ The recent literature is influenced quite heavily by Al-Qaeda's attacks in the U.S. in September 11, 2001. These attacks proved that terrorist groups have both the capacity and the willingness to cause mass destruction and death. Furthermore, other attacks illustrate this point: the February 1993 bombing of the World Trade Center, the March 1995 sarin gas attack in the Tokyo subway, the April 1995 bombing of the federal building in Oklahoma City-seemed to signal the arrival of a new and deadlier kind of terrorism- characterized by Enders and Sandler (2002, 2006, 2008), Napoleoni (2005, 2007), and Brechner (2007).

In this case of Bin Laden and Al-Qaeda, their economic and financial empire constitute a transnational financial engine, a considerable section of which is composed of legitimate businesses as already stated by Schneider (2002a, 2002b, 2004); Napoleoni (2005) and Comras (2005, 2007). According to Yepes (2008) Al-Qaeda's controlled companies in Africa included the holding company Wasi al AQuq, a Sudanese construction firm, Al-Hiraj, an ostrich farm, and shrimp boats in Kenya. In the Middlw East, the group has shares in the AlShamal Islamic Bank and large tracks of forest in Turkey; in Asia, it has agricultural holdings in Tajikistan; in Europe and the United States, holding companies, venture capital firms, banks, and import-export companies. ${ }^{5}$ Further, the importance of the Al-Qaeda network in terms of correspondent banking can be seen by examining the case of the Al Shamal Islamic Bank in Khartoum, in which foreign currency accounts were set up at Al Shamal for a number of the companies belonging to Bin Laden. Shamal's correspondent banking relationships were with a variety of reputable banks such as CityBank and others, which is why Al-Qaeda was able to move money rapidly and without impediments around the world. Alternative remittance or banking systems (ARS), i.e. Hawala, have been also important to Al-Qaeda's ability to move finances as well as generate Funds. Al-Qaeda is a terrorist network with international linkages that have been generally focused on a number of theatres of operation (sometimes in different countries), where they have managed to have money available. Their operations have been driven by a particular cause. Funding is generally specific, derived from

\footnotetext{
${ }^{4}$ For further discussion of „religious motivated terrorism groups“, see Koh (2006). She discusses the dramatic increase of identifiable religious terrorist groups from 1968 to 1992 based on the US Department of State (2003) The Patterns of Global Terrorism 2003;

${ }^{5}$ These „facts“ are taken from Shahar,Y. (2001). Tracing Bin Laden’s money. www.ict.org; and Mintz, J. (1998). Bin Laden`s Finances are Moving Target. The Washington Post.
} 
sympathetic supporters, and especially from major crime activities. Contributions in the diaspora and monies from political and religious sympathizers have been important, too.

The high flow of funds to terrorists was substantial during the cold war ${ }^{6}$ and scholars explain these flows as stemming from oil-rich Regimes that began to pump large sums of money into the terrorist financial system (e.g. Libya in the 1970s and Iran under Ayatollah Khomeini, beginning in the 1980s). Another important idea states that many of the terrorist groups of the Marxist-Leninist type of the 1960s and 1970s relied on various criminal activities particularly kidnapping, bank robberies, and extortion - to supplement their funding. Other organizations including FARC in Colombia and Shining Path in Peru financed their activities through drug trafficking (compare Yepes (2008)).

Since the mit-1970 the size of the legal international financial flows has grown to hundreds of billions of dollars a day. The same international financial system that allows commerce to flow freely between nations also provides terrorists with a way to move money around the globe within seconds. Transnational terrorism and organized crime have become a global problem, and therefore the effort to disrupt its financing ought to extend beyond borders in order to block the money wherever it is hidden and track it down wherever it moves. Barth at al (2006) argue that since 2005 and during the past 35 years, the world had nearly 20.000 terrorist incidents, ranging from the hostage takeover during the 1972 Munich Olympics to 2002 and 2005 tourist bombings in Bali. According to Barth et al. (2006) terrorist incidents worldwide during this time period have resulted in more than 90.000 casualities or injuries.

Since the events of 9/11, the nations affected and their security institutions have been facing serious challenges from transborder flows, global forces, and complex networks such as Transnational Companies, NGOs, etc. According to Bantekas (2003) and the IMF (2001), terrorism has turned out to be one of the most significant threats to (i) peace, (ii) international security and (iii) economic development from the point of view of good governance. Following Meter (2003) transnational terrorism is now perceived as a different threat compared to past dangers due to its transnational, non-state composition and its high capacity to destroy human lives and undermine states and international regimes / institutions.

\footnotetext{
${ }^{6}$ See, US.(1996). Patterns of Global Terrorism 1996 http://www.state.gov/www/global/terrorism/1996Report/overview.html. The United States actively promotes international cooperation in condemning state sponsorship of terrorism and in bringing maximum pressure to bear against state sponsors. The Secretary of State has designated seven countries as state sponsors of terrorism: Cuba, Iran, Iraq, Libya, North Korea, Sudan, and Syria.
} 


\subsection{Trends in Terrorist Financing}

In general it is very difficult to identify trends in the Money Laundering/ Terrorist Financing (ML/TF) area, because the activity of ML/TF cannot be neither observed nor recorded in statistics $^{7}$. Intelligence, law enforcement investigations, and criminal prosecution try to identify trends in connection with ML/TF. According to the Money Laundering and Terrorist Financing Typologies (FATF-GAFI 2005), the ML/FT activity could be classified by:

(i) predicate or other related offence,

(ii) country or region,

(iii) financial sector involved,

(iv) development stage of the financial market, and

(v) weak points or vulnerabilities in AML/CFT system.

The 9/11 terrorists took advantage of the lack of a financial system control, which gave them the ability to transmit and receive money with relative anonymity and to find the financial resources to carry out their plans of Al-Qaeda inspired groups and other terrorist organizations. The terrorist financing mechanisms that have emerged since September 2001 are characterized according to Geraldo at al (2007), p. 11) by "the use of formal and informal global financial system that terrorists can easily manipulate."

According to the evolution of terrorist financing explained above, it has been argued by Giraldo et al. (2007) and in the Wilton Park Report (2007) that the intelligence process to fight against terrorist financing should combine expertise from different fields to detect the various indicators and trends. The experts according the Wilton Park Conference point out that the current indicators and trends of terrorist financing are the important challenges that face international cooperation. The following list sums up the constraints presented by intelligence agencies to follow the money trail:

(1) The need for examining financial transactions will oblige national security intelligence personnel and law enforcement agents to deal with accountants and banking and financial experts if they want to follow the money trail.

\footnotetext{
${ }^{7}$ Compare here Bierstecker (2002), Costa (2005), Pieth (2005) and Schneider (2008, 2008a, 2008b).
} 
(2) Recognizing that it is necessary to analyze the suspicious activities reports collected as well as to share this information between Financial Intelligence Units of the various countries.

(3) Information should be disseminated at a local level because terrorist organizations are engaged in organized crime networks.

(4) The intelligence process against terrorist financing requires the cooperation of governments, and that of the multilateral institutions dealing with financial integrity and transnational intelligence.

\subsection{Some Common Aspects of Transnational Crime and Terrorist Groups Financing}

Similarities between transnational crime and terrorist groups are fully described by Schneider (2008a, 2008b, 2009), Sanderson (2004); Gilmore (2004), Shelley (2005); Wilkinson (2005);

Makarenko (2002, 2003a, 2003b, 2003c) and Koh (2006). They are.

(1) Both are generally rational actors,

(2) both use extreme violence and the treat of reprisals,

(3) both use kidnappings, assassinations, and extortion,

(4) both operate secretly, though at times publicly in friendly territory, and

(5) both defy the state and the rule of law(except when there is state sponsorship).

According to Masciandaro (2004, 2005, 2006), Picarelli (2006), Shelly (2007) and Yepes

(2008) the issues of transnational crime, money laundering, and the financing of terrorism have the following common aspects:

(1) They can use wire transfers or electronic payment systems to move money through multiple jurisdictions.

(2) They engage in a variety of criminal activities like traffickers and other criminal syndicates. However, the line is now becoming less defined, since terrorists often resort to crime and cooperate with criminals in generating money, obtaining arms and explosives. According to Makarenko (2003a, 2003b) criminals are likely to use terrorism tactics and random violence in pursuits of revenues:

(i) Drug, arms and human trafficking ${ }^{8}$, trading in precious stones (demands) and other commodities,

\footnotetext{
${ }^{8}$ Makarenko (2003a), p. 66 writes:”The most common criminal activity terrorist groups have been involved in is the illicit drug trade. Since the 1970s groups such as FARC, Basque Fatherland and Liberty (Euzkadi Ta Askatasuna - ETA), the Kurdistan Workers Party (Partiya Karkaren Kurdistan - PKK) and Sendero Luminoso have all been linked to the drug trade by well-documented evidence. Since the early 1990s additional groups such as Hizbullah and the IMU have also realised the finacial utility of participating in the illicit drugs trade. It is
} 
(ii) smuggled cash, cigarettes, and other addicted good,

(iii)counterfeit, goods, and

(iv) kidnapping.

Both groups benefit from: shell companies, offshore bank facilities. Money laundering experts $^{9}$, for instance, argue that both groups use a technique known as a "starburst": A deposit of dirty money is made in a bank with standing instructions to wire it in small, random fragments to hundreds of other bank accounts around the world, in both onshore and offshore financial centres. Tracking down the money becomes very difficult, since getting legal permission to pursue bank accounts in multiple jurisdictions can take years. Napoleoni (2005, p.33) argues, "You build a long chain of representative offices at the end of which there is a shell company registered offshore, and you are lucky, if you get to the end of the chain. Financial investigations often run into a blind alley always through, somewhere, in a tiny offshore office”.

\subsection{The Main Differences between Organized Crime and Terrorist Groups Financing}

It is obvious that there are many differences between organized crime and terrorist groups with respect to financing. To some extend it is possible to make a distinction in the roots and operational characteristics:

\section{(1) Terrorist Financing}

A number of scholars (Napoleoni, Krueger, Yepes) explain terrorism through religion, development of socio-political causes, and even the economy is sometimes important. Typical operational characteristics of terrorist groups and their financing are:

(i) low costs / low technology made possible some recent attacks with a great impact on human lives, on nations, and on economies (e.g. 9/11 New York, Madrid, London and Mumbai).

(ii) Flexible and decentralized organizations with independent decisions and actions.

(iii)Common ideology with indiscriminate targets (no purpose related to profit).

(iv)Financial means are needed to plan and execute (future) terrorist attacks; there is only a limited need to hide assets.

alleged that Hizbullah continues to protect heroin and cocaine laboratories in the Bekaa Valley; and evidence strongly indicated that the IMZ - prior to the Afghan campaign - controlled drug trafficking routes into Central Asia from northern Afghanistan”.

${ }^{9}$ See: Koh (2004), Schneider (2004, 2008a, 2008b, 2009); Savona (2002); and Masciandaro (2004). 
(v) Self-financing with possible criminal activities but also obtaining money from legal sources (e.g., donations and charity organizations). Terrorists use different sources of money, depending on their motivations, their mode of operations, and the resistance they face from law enforcement. Quite often the money starts off clean, becoming "dirty" only when the terrorist crime is committed later on. Hence, terrorist enterprises use clean money to commit crimes. The money sometimes consists of legally obtained resources that are used for a limited period of time and of smaller amounts of money to prepare attacks.

\section{(2) Organized (Transnational) Crime Turnover and Money Laundering ${ }^{10}$}

Dirty money is earned through various criminal activities, like drug, weapon and human trafficking. How much illicit crime money in all its forms can be observed? Baker (2005) estimates the illicit money to range between US\$ 1.0 and 1.6 trillion a year. This estimate has been adopted by the World Bank. Moreover, Baker estimates that half - US\$ 500 to 800 a year - comes out of developing and transitional economies. These are countries that often have the weakest legal and administrative structures, the largest criminal gangs of drug dealers, and, far too often, economic and political elites who want to take their money out by any means possible.

In table 2.1, the global flows from illicit activities worldwide are shown. In crossborder illicit financial flows, the proceeds of bribery and theft are the smallest, at only perhaps three percent of the global total. Criminally generated funds account for some 30 to 35 percent of the global total. Commercially tax evading money, driven in particular by abusive transfer pricing and faked transactions as well as mispricing is by far the largest component, at some 60 to 65 percent of the global total.

\footnotetext{
${ }^{10}$ For a detailed analysis see Schneider (2008a, 2008b and 2009), Schneider and Windischbauer (2008), Schneider, Dreer and Riegler (2006), and Takats (2007).
} 
Table 2.1: Global Flows from Illicit Activities worldwide, years 2000/2001

\begin{tabular}{|c|c|c|c|c|}
\hline Global Flows & Low (US\$ bn) & $\%$ & High (US\$ bn) & $\%$ \\
\hline Drugs & 120 & $11 \%$ & 200 & $12.5 \%$ \\
\hline Counterfeit goods & 80 & $7.5 \%$ & 120 & $7.5 \%$ \\
\hline Counterfeit currency & 3 & $0.2 \%$ & 3 & $0.2 \%$ \\
\hline Human trafficking & 12 & $1.1 \%$ & 15 & $0.9 \%$ \\
\hline Illegal arms trade & 6 & $2.0 \%$ & 10 & $0.6 \%$ \\
\hline Smuggling & 60 & $5.6 \%$ & 100 & $6.3 \%$ \\
\hline Racketeering & 50 & $4.7 \%$ & 100 & $6.3 \%$ \\
\hline Crime subtotal & 331 & $31.2 \%$ & 549 & $34.3 \%$ \\
\hline Mispricing & 200 & $18.9 \%$ & 250 & $15.6 \%$ \\
\hline Abusive transfer pricing & 300 & $28.3 \%$ & 500 & $31.2 \%$ \\
\hline Fake transactions & 200 & $18.9 \%$ & 250 & $15.6 \%$ \\
\hline Commercial subtotal & 700 & $66.0 \%$ & 1,000 & $62.5 \%$ \\
\hline Corruption & 30 & $2.8 \%$ & 50 & $5.1 \%$ \\
\hline Grand Total & 1,061 & $100.0 \%$ & 1,599 & $100.0 \%$ \\
\hline
\end{tabular}

Source: Baker (2005)

In the next step the main characteristic of money laundering is to make dirty money appear legal (compare Walker (2000, 2004, 2007)). There are numerous methods of money laundering; in table 2.2 the 12 most important methods are shown. Which of these methods is mostly used, depends on the crime activity and on the specific institutional arrangements in a country where the criminal money is "earned". For example, in the drug business method 8, business ownership, is quite often used. In the drug business and in big cities smaller amounts of cash are earned by drug dealers in a lot of different spaces, which they infiltrate in to cash intensive operations such as restaurants which are especially well suited for money laundering purposes. But also cash deposits (the so called smurfing method) or illegal gambling is quite often used. Obviously, these methods clearly show, there are a number of ways to launder money. It might be more efficient to reduce the crime activities then to fight against these methods. 
Table 2.2: The Methods of Money Laundering ${ }^{1)}$

\begin{tabular}{|c|c|c|}
\hline 1) & $\begin{array}{l}\text { Wire transfers } \\
\text { or electronic } \\
\text { banking }\end{array}$ & $\begin{array}{l}\text { The primary tool of money launderers to move funds around in the } \\
\text { banking system. These moves can conceal the illicit origins of the } \\
\text { funds or just place the money where the launderers need them. Often } \\
\text { the funds go through several banks and even different jurisdictions. }\end{array}$ \\
\hline 2) & Cash deposits & $\begin{array}{l}\text { Money launderers need to deposit cash advances to bank accounts } \\
\text { prior to wire transfers. Due to anti-money-laundering regulations they } \\
\text { often 'structure' the payments, i.e. break down large to smaller } \\
\text { amounts. This is also called 'smurfing'. }\end{array}$ \\
\hline 3) & $\begin{array}{l}\text { Informal value } \\
\text { transfer } \\
\text { systems (IVTS) }\end{array}$ & $\begin{array}{l}\text { Money launderers need not rely on the banking sector, other transfer } \\
\text { providers, such as the hawala or hindi are readily available to } \\
\text { undertake fund transfers. These systems consist of shops (mainly } \\
\text { selling groceries, phone cards or other similar items), which are also } \\
\text { involved in transfer services. IVTSs enable international fund } \\
\text { transfers, as these shops are present in several jurisdictions. }\end{array}$ \\
\hline 4) & $\begin{array}{l}\text { Cash } \\
\text { smuggling }\end{array}$ & $\begin{array}{l}\text { Money launderers might mail, Fedex or simply carry cash with them } \\
\text { from one region to another, or even to different jurisdictions. }\end{array}$ \\
\hline 5) & Gambling & $\begin{array}{l}\text { Casinos, horse-races and lotteries are ways of legalizing funds. The } \\
\text { money launderer can buy (for 'dirty' cash) winning tickets - or in the } \\
\text { case of casinos chips - and redeem the tickets or the chips in a 'clean' } \\
\text { bank check. Afterwards, the check can be easily deposited in the } \\
\text { banking sector. }\end{array}$ \\
\hline 6) & $\begin{array}{l}\text { Insurance } \\
\text { policies }\end{array}$ & $\begin{array}{l}\text { Money launderers purchase single premium insurance (with dirty } \\
\text { cash), redeem early (and pay some penalty) in order to receive clean } \\
\text { checks to deposit. Longer term premium payments might make } \\
\text { laundering even harder to detect. }\end{array}$ \\
\hline 7) & Securities & $\begin{array}{l}\text { Usually used to facilitate fund transfers, where underlying security } \\
\text { deals provide cover (and legitimate looking reason) for transfers. }\end{array}$ \\
\hline 8) & $\begin{array}{l}\text { Business } \\
\text { ownership }\end{array}$ & $\begin{array}{l}\text { Money might be laundered through legitimate businesses, where } \\
\text { laundering funds can be added to legitimate revenues. Cash-intensive } \\
\text { operations, such as restaurants, are especially well suited for } \\
\text { laundering. }\end{array}$ \\
\hline 9) & $\begin{array}{l}\text { Shell } \\
\text { corporations }\end{array}$ & $\begin{array}{l}\text { Money launderers might create companies exclusively to provide } \\
\text { cover for fund moves without legitimate business activities. }\end{array}$ \\
\hline 10) & Purchases & $\begin{array}{l}\text { Real estate or any durable good purchases can be used to launder } \\
\text { monies. Typically, the item is bought for cash and resold for clean } \\
\text { monies, like bank checks. }\end{array}$ \\
\hline 11) & $\begin{array}{l}\text { Credit card } \\
\text { advance } \\
\text { payment }\end{array}$ & $\begin{array}{l}\text { Money launderers pay money in advance with dirty money, and } \\
\text { receive clean checks on the balance from the bank }\end{array}$ \\
\hline 12) & $\begin{array}{l}\text { ATM } \\
\text { operations }\end{array}$ & $\begin{array}{l}\text { Banks might allow other firms to operate their ATMs, i.e. to maintain } \\
\text { and fill them with cash. Money launderers fill ATMs with dirty cash, } \\
\text { and receive clean checks (for the cash withdrawn) from the bank. }\end{array}$ \\
\hline
\end{tabular}

Schneider (2008a, 2008b) estimates with the help of the MIMIC estimation procedure that money laundering from organized transnational crime has increased from 1995 USD 273 billion (1,33\% of official GDP) to USD 603 billion (or 1,74\% of the official GDP) in 2006 for 
20 OECD countries (Australia, Austria, Belgium, Canada, Denmark, Germany, Finland, France, Greece, Great Britain, Ireland, Italy, Japan, Netherlands, New Zealand, Norway, Portugal, Switzerland, Spain and the United States). On a world wide basis in 2006 USD 600 billion are estimated to be laundered coming only from the drug (crime) business.

Unger (2007) estimates the amount of laundered money and their top 20 destinations, which is shown in table 2.3 over the time span 1997-2000. Here two estimates are presented, one by Walker (1999, 2007) and one by the IMF. The Walker figure is with 2.850 billion USD much larger then the IMF figure with 1.500 billion USD (both figures are for the year 2005). Walker's figures have been criticized as much to high which was one reason why the IMF estimates have been choosen, too. Table 2.3 clearly shows that two thirds of worldwide money laundering was sent to the top 20 countries listed. One should realize, that most of these countries are very established, well developed and have a quite sizeable legal/official economies. What is also amazing, that there are only a few microstate offshore countries (OFCS) and tax heavens among them (Cayman Islands, Vatican City, Bermuda and Liechtenstein $)^{11}$. The majority of countries that attract money laundering flows are economic prepotencies at not tiny unimportant countries. The United States has the largest worldwide share of money laundering of almost $19 \%$, followed by the Cayman Islands (4,9\%), Russia $(4,2 \%)$, Italy $(3,7 \%)$, but also smaller countries like Switzerland $(2,1 \%$ of worldwide money laundering), Liechtenstein (1,7\%) and Austria (1,7\%) are also quite attractive. If one takes the lower IMF value for Austria, Switzerland and in the United Kingdom, roughly $5.5 \%$ of the total amount is laundered, which comes close to roughly $10 \%$ of official GDP of the three countries However, it should be clearly stated that it is not clear whether this money is only laundered in these countrie or stays in these countries. It might leave these countries when it was laundered. In general, table 2.3 clearly demonstrates, how important the amount of laundered money is and that two thirds of this are concentrated in 20 countries.

Bagella, Busato and Argentiero (2009, pp.881) use a theoretical two-sector dynamic general equilibrium model to measure ML for the United States and the EU-15 macro areas over the sample 2000:01-2007:01 at a quarterly frequency. Their series are generated through a fully micro-founded dynamic model, which is appropriately calibrated to replicate selected stochastic properties of the two economies. Their model (and the analysis) has a short run perspective, and for this reason, the paper discusses the stochastic properties of the Hodrick-

\footnotetext{
${ }^{11}$ Compare also Masciandaro (2005, 2006), Masciandaro and Portolano (2004), Zdanowicz (2009), Truman and Reuter (2004), and Walker and Unger (2009):
} 
Prescott filtered series. Bagella et al. (2009, pp.881) got the following results: First the simulations show that ML accounts for approximately 19 percent of the GDP measured for the EU-15, while it accounts for 13 percent in the US economy, over the sample 2000:012007:04. Second, the simulated ML appears less volatile than the corresponding GDP. As regards the EU-15 macro area, the simulated statistics suggest that ML volatility is one-third of the GDP ones; for the US economy, the same statistics produce a figure of two-fifths. Considering these estimates one must admit, that they are pretty high and unfortunately no consistent check was done by Bagella et. al, whether such figures are plausible.

Table 2.3: The Amount of Laundered Money and Top 20 Destinations of Laundered Money, Year 2005

\begin{tabular}{|l|l|c|c|c|}
\hline Rank & Destination & $\begin{array}{c}\text { \% of } \\
\text { worldwide } \\
\text { money } \\
\text { laundering }\end{array}$ & $\begin{array}{l}\text { Walker estimate 2.85 } \\
\text { trillion US\$ } \\
\text { Amount in billion US\$ }\end{array}$ & $\begin{array}{l}\text { IMF estimate of 1.5 } \\
\text { trillion worldwide } \\
\text { Amount in billion US\$ }\end{array}$ \\
\hline 1 & United States & $18.9 \%$ & 538,145 & 283,500 \\
\hline 2 & Cayman Islands & $4.9 \%$ & 138,329 & 73,500 \\
\hline 3 & Russia & $4.2 \%$ & 120,493 & 63,000 \\
\hline 4 & Italy & $3.7 \%$ & 105,688 & 55,500 \\
\hline 5 & China & $3.3 \%$ & 94,726 & 49,500 \\
\hline 6 & Romania & $3.1 \%$ & 89,595 & 45,500 \\
\hline 7 & Canada & $3.0 \%$ & 85,444 & 42,000 \\
\hline 8 & Vatican City & $2.8 \%$ & 80,596 & 42,000 \\
\hline 9 & Luxembourg & $2.8 \%$ & 78,468 & 36,000 \\
\hline 10 & France & $2.4 \%$ & 68,471 & 34,500 \\
\hline 11 & Bahamas & $2.3 \%$ & 66,398 & 3,000 \\
\hline 12 & Germany & $2.2 \%$ & 61,315 & 28,500 \\
\hline 13 & Switzerland & $2.1 \%$ & 58,993 & 25,500 \\
\hline 14 & Bermuda & $1.9 \%$ & 52,887 & 25,500 \\
\hline 15 & Netherlands & $1.7 \%$ & 49,591 & 25,500 \\
\hline 16 & Liechtenstein & $1.7 \%$ & 48,949 & 24,000 \\
\hline 17 & Austria & $1.7 \%$ & 48,376 & 24,000 \\
\hline 18 & Hong Kong & $1.6 \%$ & 44,519 & 18,000 \\
\hline 19 & United Kingdom & $1.6 \%$ & 44,478 & $1,006,500$ \\
\hline 20 & Spain & $1.2 \%$ & 35,461 & \\
\hline & SUM & $67.1 \%$ & $1,910,922$ & \\
\hline 15 So & & & \\
\hline
\end{tabular}

1) Source Unger (2007, page 80)

From a global perspective for 2000, the IMF (2003, 2001) as well as the World Bank estimate that $2-4 \%$ of the world gross domestic product (GDP) stem from illicit (criminal) sources. Agarwal and Agarwal (2006) estimate from economic intelligence units, that global money laundering amounts to more than 2.0 to 2.5 trillion US\$ annually or about 5-6\% of World 
GDP in 2006 (4,444 trillion US\$ in 2006) to be contrasted against an observed figure of US\$ 500 billion to one trillion in 2004 from the same authors (Agarwal and Agarwal (2004)). Recent IMF estimates on money laundering by the drug traffickers, who "introduce" the proceeds gained through the selling of drugs into the legitimate financial market, amount to 600 billion annually. The IDB (2004) reaches the conclusion that for Latin America a rough estimate appears to be somewhere between 2.5 and $6.3 \%$ of annual GDP of Latin American countries.

In their latest study again Walker and Unger (2009, page 821) undertake an attempt, measuring global money laundering and the proceeds of transnational crime that are pumped through the financial system worldwide. They criticize that methods such as case studies, proxy variables, or models for measuring the shadow economy all tend to under- or overestimate money laundering. They present a model, which ia a gravity model which makes it possible to estimate the flows of illicit funds from and to each jurisdiction in the world and worldwide. This “Walker Model” was first developed in 1994, and used and updated recently. The authors show that it belongs to the group of gravity models, which have recently become popular in international trade theory. Using triangulation, they demonstrate, that the original Walker Model estimates are compatible with recent findings on money laundering. Once the scale of money laundering is known, its macroeconomic effects and the impact of crime prevention, regulation and law enforcement effects on money laundering and transnational crime can also be measured. Walker and Unger (2009, p. 849-850) conclude, that their model still seems to be the most reliable and robust method to estimate global money laundering, and thereby the important effects of transnational crime on economic, social and political institutions. Rightly they argue, that the attractiveness and distance indicator in the Walker model are a valid first approximation, but are still quite ad hoc. A better micro-foundation for the Walker Model will be needed in the future. For this, the behavior of money launderers, and in particular what makes them send their money to a specific country, is important. Hence, Walker and Unger (2009, p. 850) argue that an economics of crime micro-foundation for the Walker Model would mean that, similarly to international trade theory, behavioral assumptions about money launderers have to be made. The gravity model must be the (reduced form) outcome of their rational calculus of sending their money to another country and possibly getting caught, but potentially making large profits. 


\subsection{The Various Terrorist Financing Sources}

\subsubsection{Legitimate Sources of Terrorist Financing}

Not all the financing received by terrorist comes from illegal activities. Yepes (2008) argues, that the legitimate financing is related to completely legal activities conducted by charities, diaspora, and firms. The 9/11 commission pointed out a core number of financial facilitators involved in raising, moving, and storing the money Al Qaeda used - from donors primarily in the Gulf Region but also from other countries around the world. According to Comras (2007) these groups used legitimate charities and businesses as covers to develop a substantial financial network.

\section{(1) State Sponsors}

According to Yepes (2008) Afghanistan and Sudan have been sponsoring terrorist groups, e.g. it has been proven that the majority of companies and banks used by Bin Laden were located in Khartoum (Sudan) such as Faisal Islamic Bank, Ladin International, Taba investment Co. Ltd, Al Themar Al Mubaraka, Al Qudarat, Islamic Bank Al Shama.

\section{(2) Private (Individual and Corporate) Donors}

Kohlmann (2006) and Simpson (2007a, 2007b, p.10) conclude, that among the most important cases of the private donors involved in terrorist financing, is Mr. Al Rajhi and his family members, "they have been major donors to Islamic charities that are suspected by Western intelligence agencies of funding terrorism, according to CIA reports and federalcourt filing by the US Justice Department. An endowment holding much of Saleh Al Rajhi's wealth gives and indication of the scale. His Web site details nearly USD 50 Mio. in direct donations within the kingdom to Islamic causes and at least USD 12 Mio. in donations abroad. The overseas money went to aid embattle Muslims in Kosovo Chechnya and the Palestinian territories and to finance Islamic instruction”. According to Simpson (2007b), the U.S. Justice Department is investigating possible criminal tax-law violations by a Boston private-equity firm that manages hundreds of millions of dollars for Muslim investors in Europe and the Middle East and is affiliated with a Swiss investment group that U.S. authorities suspect of financing Islamic extremists. Some private corporate donors have been cited in Morigi (2004), and furthermore, Fried et al. (1975) concludes that private individual and corporate donors could be related to those individuals or enterprises that recycled Petrodollars in 1974. 


\section{(3) Ethnic Communities and Religious Financing}

According to Comras (2007) the factor explaining religious financing consists in a "Coranic Tax”, explaining the support offered by from the richest to the poorest, and it is obligatory to pay this within the Islamic community. Charity forms a very important part of Muslim law an tradition. Furthermore Comras (2007) argues, that Al Qaeda took advantage of it to solicit funds through collection boxes at mosques and Islamic centres. Simularily Napoleoni (2005, p.22) argues that the Mosque Network seems to provide financial support for the Jihad. He writes: "The Mosque Network is as efficient as ever and continues to be the main vehicle through which Islamist organizations, countries, state-shells, armed groups and their sponsors link up and do business with each other”.

\section{(4) Charities}

Donations to NGOs and charities are perfectly legal in most countries, but the problem arises when some objectives of a NGO are not legal or are linked to a diversion of some of the funds legally received for illegal activities. Kohlmann (2006) and Raphaeli (2003) have highlighted how terrorist organizations have resorted to a variety of charitable as well as front and fraudulent organizations to mobilize financial resources for terrorists to carry out their actions. Raphaeli demonstrates the linkage between charity and terrorism in the case of Enaam Arnaout. Arnaout served in the office of an organization known as Maktab al Khidamat, run principally by Sheikh Abdullah Azzam and Osama bin Laden, for the purpose of providing logistical support to the Mujahideen (holy warriors) who were fighting the Soviet Union in Afghanistan.

In Eaton's (2007) work with the title "The Role of Islamic Charities in International Terrorist Recruitment and Financing” the author notes that a number of sympathetic NGOs provided various kinds of assistance, which proved to be invaluable in the long term struggle and in explaining the roots of support of contemporary radicalisation.

\section{(5) Legal Business}

The truly transnational financial engine of the Al Qaeda terrorist group and its sympathizers continue to raise money through their own business activities. The legal business support to terrorist activities are noted by Napoleoni (2005), Gunaratna (2003), Schneider (2004, 2008a, 2008b), Millard (2006) and Comras (2007). Following Napoleoni (2005) and Mintz (1998) the Al-Qaeda group consists of the following companies among others: In Africa, a holding company, Wadi al Aqiq, a Sudanese construction firm, Al Hiraj, an ostrich farm and shrimp 
boats in Kenya; in the Middle East shares in the As-Shamil Islamic Bank and large tracks of forest in Turkey; agricultural holdings in Tajikistan in Europe and the United States, holding companies, venture capital firms, banks and import-export companies. The portfolio includes real estate in London, Paris and French Riviera; dairy business in Denmark; wood and paper industries in Norway; and hospital equipment in Sweden. Some scholars like Comras (2007) paid attention to the use of trusts by terrorists groups. The use of networks of companies and shell companies, shell bank, and offshore trusts to raise money, hide assets, and protect their identity of other financial contributors.

\subsubsection{The Illegal Sources of Terrorist Financing}

\section{(1) Drug Trafficking}

According to Yepes (2008) in May 2002 a report called "Global Overview of NarcoticsFunded Terrorist and Other extremist groups” was launched, prepared by the Federal Research Division of the Library of Congress and the US Department of Defence. The report examined connections between extremist groups and narcotics trafficking in the following regions of Latin America: Triborder Region (Argentina, Brazil, and Paraguay), Colombia, and Peru; in the Middle East: Lebanon, in Southern Europe (Albania and Macedonia); in Central Asia: Kyrgyzstan, Tajikistan, and Uzbekistan and in East Asia: The Philippines.

\section{(2) Oil Smuggling}

According to Johnson (2001) and Napoleoni (2005) another business is oil smuggling, where terror, criminal, and legitimate economies interact. Countries, where oil smuggling is a significant problem are Thailand, China, Russia, Cambodia, Iran and Tanzania. In all these countries oil smuggling earn for themselves significant profits, a substantial portion of which enters the laundering cycle. Oil smuggling is also related to arms trade.

\section{(3) Arms / Diamonds Trafficking}

Besides drugs trafficking according to Levi and Gilmore (2002), Schneider (2004, 2008a, 2008b, 2009) and Yepes (2008) arms trafficking, and illegal diamonds trade are some of the most important illegal sources of funding of terrorist groups. The illicit arms trade demonstrates how comparatively easy it is to obtain false documentation accompanying arms shipments, especially end-user certificates. Inconsistent documentation requirements between states, and inefficient control in customs and port authorities in many states, have created an 
environment in which the illicit arms trade does not need to rely entirely on criminal activities:

(1) When a state is involved in supplying arms to an embargoed state, payments often come in the form of commercial payments, such as an "oil for arms" deals to avoid bank involvement.

(2) When an arms broker supplies an embargoed state of an insurgent/terrorist group, banks are often used because shipments are usually paid for in the form of letters of credit of by the direct transfer of hard-currency funds. In this case, money laundering becomes an important factor to ensure that the final arms destination is disguised. It is at this point that offshore banks play an important role because their facilities can ensure that any deposit or transfer is routed via several intermediary institutions; and deposits or transfers can be conducted in the name of a series of shell companies. Both of these techniques are used to hide the financial trail behind multiple administrative layers.

(3) In situations where access to normal banking channels is very difficult (for example, as with most non-state actors), the financing of arms deals often takes a different form, most often through commodity exchanges. According to Smillie et al (2000), illicit arms transfers to Liberia and Sierra Leone were often financed with diamonds and timber concessions.

\subsubsection{Summary}

In figure 2.1 the various channels of the infiltration of the transnational terrorist groups are summarized. Figure 2.1 concentrates on the use of financial resources and clearly demonstrates that the financial means / flows stand on 5 pillars ranking from donations to criminal activities. 
Figure 2.1: Infiltration of the Transnational Terrorism in the Economy

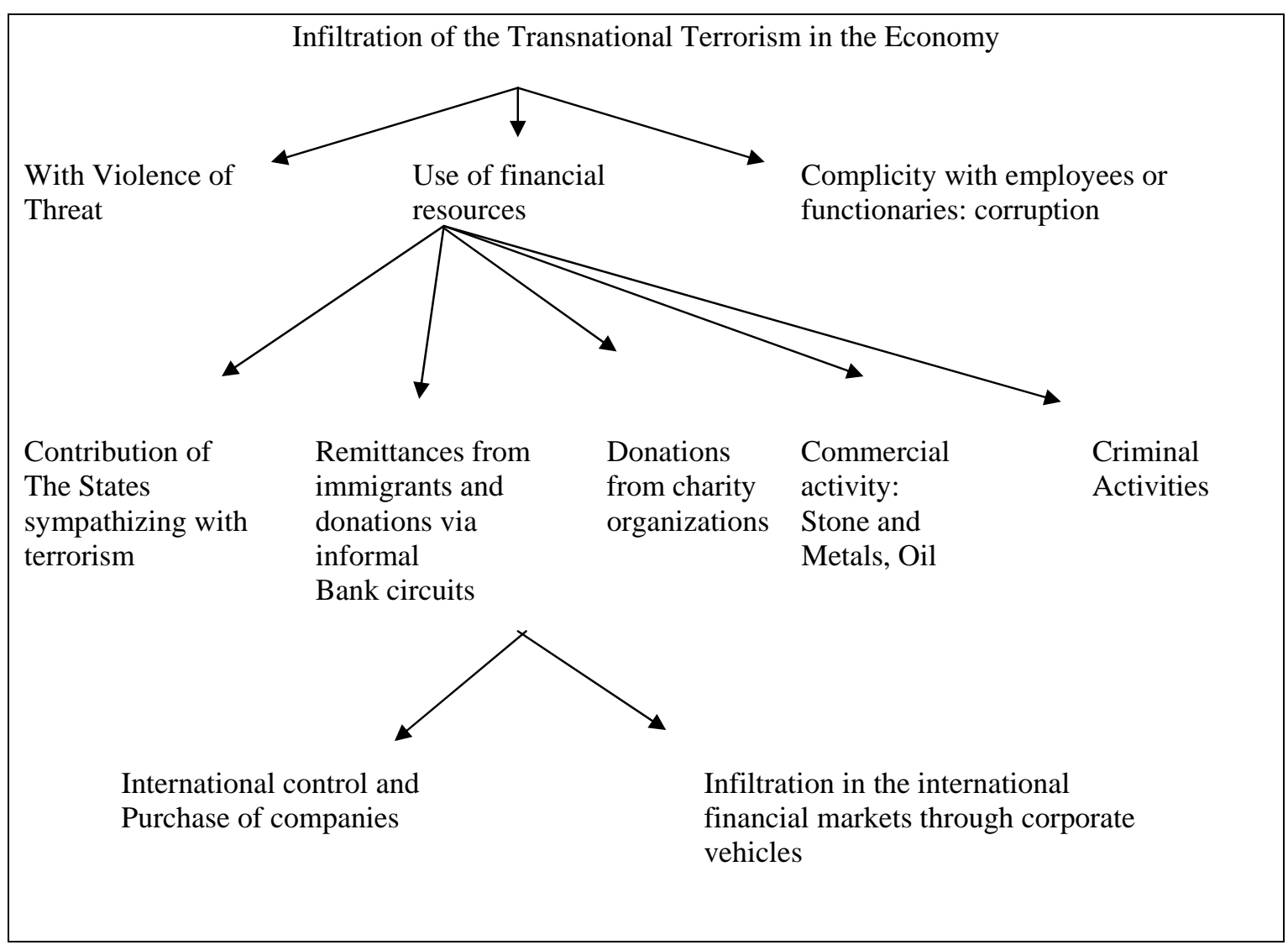

Source: Yepes (2008, p. 56)

\subsection{The Informal Money Transfer (Hawala) System}

Especially during the 1990s, international concern grew over the "underground banking” and its abuse by serious offenders. Some academic works by Williams (2007), Savona (1997) and El-Quorchi (2003) have explained how informal systems operate, including their risks. The Informal Value Transfers Systems (IVTS) changes from region to region (Hawala or door-to door). Some scholars (Williams (2007), El-Quorchi (2003)) argue that hawala is vulnerable to criminal abuse, and like the other financial institutions, there is evidence that money derived from drug trafficking, illegal arms sales, body part trade, corruption, tax evasion, and all kinds of fraud have indeed moved through Hawala networks.

Hawala banking still takes place up to now and there is some of literature (Passas (2005), Bunt (2007)) about the Hawala banking system, where these authors point to the need for a regulation of the Hawala system. As argued, another way to transfer criminal financial flows is the Hawala banking. According to Bunt (2007), Hawala bankers ${ }^{12}$ are financial service

\footnotetext{
${ }^{12}$ Several traditional terms, like Hundi (India) and Fei-ch'ein (China) remind one of the fact that hawala banking came up independently in different parts of the world. At present, a range of other terms is used to refer to the
} 
providers who carry out financial transactions without a license and therefore without government control. They accept cash, cheques or other valuable goods (diamonds, gold) at one location and pay a corresponding sum in cash or other remuneration at another location. Unlike official banks, Hawala bankers disregard the legal obligations concerning the identification of clients, record keeping, and the disclosure of unusual transactions, to which these official financial institutions are subject.

To summarize: Through the Hawala system that forms an integral part of the informal black market economy, underground bankers ensure the transfer of money without having to move it physically or electronically. When a payment needs to be made overseas, the underground banker will get in touch with a courier (or more recently using email, fax or phone) in that country informing him of the details of making the payment. If the recipient of the payment wishes to personally obtain the money, a code referring to the underground banker in the country of payment is given to the recipient. Such a system is almost untraceable since it leaves little if any paper trail. Transaction records are, if they are kept at all, being kept only until the money is delivered, at which time they are destroyed. Even when there is a paper or electronic record of sorts it is often in dialects and languages that serve as de facto encryption system.

According to Fischer (2002,p.17) the annual turnover of the Hawala banking system in the early 70ties was already 60 billion USD in the Arabic countries; e.g. six million foreign labourers in Saudi Arabia, who are sending home 40 billion USD a year home, make substantial use of the "ethnic” Hawala system. Fletcher and Baldrin (2002, p. 119) estimate with regard to Pakistan that 2.5 billion USD inherit the country in remittances via the Hawala system in 2001; the amount of money in India's Hindi system was 50 billion USD in 1971. Despite the growing competition by formal remittance services, the use of Hawala banking has probably not declined. According to a recent estimate by the IMF, (especially Asian) migrants transfer 100 billion dollars per annum to family members and relations in their country of origin through the official financial system. In addition, a similar amount of money is transferred in the form of goods, cash, and through underground bankers (IMF 2005).

According to Bunt (2007), there are at least two different perspectives on Hawala banking. From the first point of view, Hawala banking is regarded as a centuries-old institution which

same phenomenon, such as 'informal banking', 'underground banking', 'ethnic banking' or 'informal value transfer system’. 
has not yet outlived its usefulness. Low-income workers and migrant workers in particular supposedly put more trust in Hawala bankers than in formal banks. This viewpoint emphasizes the problem associated with subjecting Hawala banking to the same rules as formal banks. Regulation either through registration or licensing is seen as ineffective because it will simply push the system further into the underground, further complicating the already problematic task of controlling Hawala transactions (Razavy (2005), p.292; Perkel (2004), p.210-211)). Hence, Hawala banking might be the closest thing of a free market banking, without government regulation and it functioned well for centuries. One should clearly emphasize these advantages of Hawala banking when criticizing it. From the opposite point of view, Bunt (2007) argues that Hawala banking is described as 'underground banking', a system that flies under the radar of modern supervision of financial transactions. Underground banking is considered a threat to the effectiveness of anti-money laundering measures and the fight against terrorist financing. To prevent underground bankers from becoming a safe haven for criminals and terrorists, they should be subject to the standard regulations regarding record keeping, disclosure of unusual transactions and identification of clients ${ }^{13}$.

\subsection{Summary: The Principal Sources of Terrorist Financing}

The sources of terrorist financing, which are channeled through formal and informal systems, come from a variety of origins, some criminal, some not. As discussed the most important are:

(1) Domestic - individual and corporate: voluntary contribution;

(2) Diaspora-migrant communities: voluntary contribution;

(3) Co-ethnic and co-religious support: donations and contributions from people with religious or ethnic affinity;

(4) State-sponsorship: patron states supporting terrorist group;

(5) Public and private donors and individual financiers who support terrorist-controlled, social and religious organizations;

(6) High level organized crime: fraud, illegal production and smuggling of drugs, kidnapping, armed robbery, trafficking in human beings;

(7) Investments and legitimate business: money is used to acquire enterprises and engage in trade with profits being used to finance terrorism; and

(8) Non-governmental organizations and community organizations: terrorist organizations set up front organizations which receive funds from sister NGO's in other countries or infiltrate established community organizations which receive grants.

\footnotetext{
${ }^{13}$ Compare also Richard (2005) and Rider (2004).
} 


\section{The Amount of Financial Flows and the Ways of Financing Islamistic International Terror Organizations}

The financing of cells of (Islamistic) terrorist organizations is conducted independently, and financial transactions are deliberately targeted at single cells in order to avoid moving larger sums and calling attention. Usually these transactions are carried out with the help of traditional trading companies (for example within the scope of exporting honey in the Middle East). They are camouflaged to an extent that makes tracing them nearly impossible. This form of transactions is barely distinguishable from normal import/export or other monetary dealings. ${ }^{14}$ Hence, in this chapter an attempt is made to estimate the amount of financial flows and to analyse the ways of financing international terror organizations. Before showing the results the estimation procedure is shortly described.

\subsection{Estimation Procedure (latent estimator MIMIC approach)}

As the size of financial flows of the Islamic terrorist groups is an unknown (hidden) figure, a latent estimator approach using a MIMIC (i.e. multiple indicators, multiple causes estimation) procedure is applied. This method has quite successfully been used to estimate the size of the shadow economy and is now shortly described. ${ }^{15)}$ This estimation procedure is called the "model approach" which explicitly considers the multiple causes of as well as multiple indicators of the hidden variable. The method is based on the statistical theory of unobserved variables, which consider multiple causes and multiple indicators of the phenomenon (size of the shadow economy, size of the financial flow of (Islamistic) terror organizations). A factoranalytic approach is used to measure the hidden economy (here size of financial flows of the terrorist organizations) as an unobserved variable over time. The unknown coefficients are estimated in a set of structural equations within which the "unobserved" variable cannot be measured directly. The MIMIC (multiple-indicators multiple-causes) model consists in general of two parts, the measurement model links the unobserved variables to observed indicators. The structural equations model specifies causal relationships among the unobserved variables. In this case, there is one unobserved variable, the size of the financial flows of (Islamistic) terrorist organizations. It is assumed to be influenced by a set of indicators for these financial flows, thus capturing the structural dependence of these financial

\footnotetext{
${ }^{14}$ See: Schneider (2004, 2002a, 2002b).

${ }^{15)}$ For a detailed discussion compare Schneider and Enste (2000) and Schneider (2005).
} 
flows on variables that may be useful in predicting its movement and size. The interaction over time between the causes $Z_{i t}(i=1,2, \ldots, k)$, the size of these financial flows $X_{t}$, and the indicators $Y_{j t}(j=1,2, \ldots, p)$ is shown in figure 3.1.

Figure 3.1: Development of the shadow economy (size of financial flows of Islamic terrorist organizations) over time

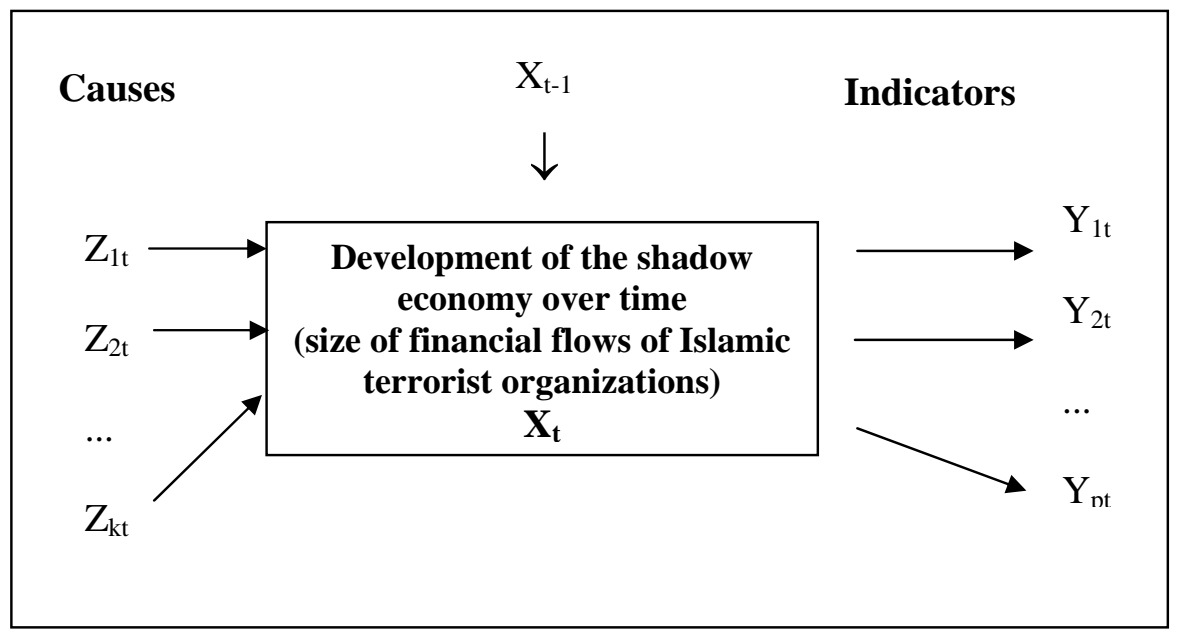

\subsection{The Estimation Results}

As causes for the estimation of the size of the financial flows of the Islamistic terrorist groups I have the following variables:

(1) number of active members and active supporters (positive sign expected);

(2) tribute payments from Islamic countries (positive sign expected);

(3) financial flows from wealthy people and from Islamic religious organizations in Islamic countries (positive sign expected);

(4) illegal amount of diamond trading (positive sign expected);

(5) illegal amount of drug trading (positive sign expected); and

(6) GDP per capita in Islamic countries (negative sign expected).

As indicators I use the following variables:

(1) the cash flows in Islamic countries (positive sign expected);

(2) the rate of GDP adjusted for the means of all Islamic countries (negative sign expected), and

(3) the amount of currency trading (positive sign expected). 
Figure 3.2

In Figure 3.2 the estimation (MIMIC approach) of the financial flows (unobserved / latent variable) of over 8 terrorist organizations and over the period 1999 to 2006 is shown. If we first turn to the causal variables, the number of active members and number of supporters, the tribute payments from Islamistic countries, the financial flows from wealthy people and from Islamic religious organizations have the expected sign and the estimated coefficients are highly statistically significant. This is also true for the causal variable, amount of illegal drug trading, which has the expected sign and is statistically significant. The amount of illegal diamond trading and GDP per capita in Islamic countries have the expected signs, but are not statistically significant using the usual confidence intervalls. Hence, out of the 6 variables 4 turn out to be highly statistically significant. If I now turn to the indicator variables, all 3 have the expected signs and are statistically significant. Starting with the variable cash currency flows in Islamic countries and continuing to the one, the amount of currency trading between Islamic countries as well as the rate of GDP. This estimation shows, that there is systematic relationship between the major courses of financial sources for the financing of Islamistic terrorist groups and important indicator variables.

The MIMIC method has the disadvantage, that one gets only relatively estimated values and not absolute ones, hence one has to calibrate these values with the help of other estimations into absolute ones. Doing this ${ }^{16} \mathrm{I}$ achieve the following two results. The main results are shown in tables 3.1 and 3.2. The first can be demonstrated in the case of Al-Qaeda.

\section{Tables 3.1 and 3.2}

Considering table 3.1 one realizes that over 1999-2004 the annual financial flows (i.e. the budget) of Al-Qaeda varies between 20 to 50 million USD per year. What is the origin/source of these annual financial flows? This is shown in the second part of table 3.1. The drug business (mainly transporting drugs) contributes 30-35\%, donations and tribute payments of governments of wealthy individuals, and of religious groups vary between $35-50 \%$ and classical crime activities (i.e. blackmail and mostly kidnapping) contribute between 10-15\%.

\footnotetext{
${ }^{16}$ See here Schneider (2008a, 2008b. 2009)
} 
In table 3.2 a rudimentary overview is given about the preliminary results of the financial flows of 8 Arabic and Islamistic terror organizations. Table 3.2 shows that the financial flows of these 8 Islamistic terror organizations are quite small but (compared to the ones of the organized crime scene) but that they have enough financial means to train and to equip well their active terrorist members in order to create a maximum of destruction. If one compares these financial flows with the overall figure of "dirty or crime money" given by the IMF these financial flows of Islamic terrorist organizations are of minor importance with respect to magnitude: The IMF calculates that the total sum of "dirty money” being whitewashed through the financial system ranks between 500 billion USD and 1,500 billion USD a year, which amounts up to $3 \%$ and $5 \%$ of the gross world product. The financial flows of Islamic terrorist organizations range between 0,9 and $5,8 \%$ of the total sum of "dirty money“. 
Figure 3.2: Estimation (latent estimator approach) of the financial flows (budget) of Islamistic terrorist groups using causes (determinants) and traces (indicators), MIMIC estimation procedure, combined cross section and time series over 8 Islamistic terrorist org. and over 1999 to 2006

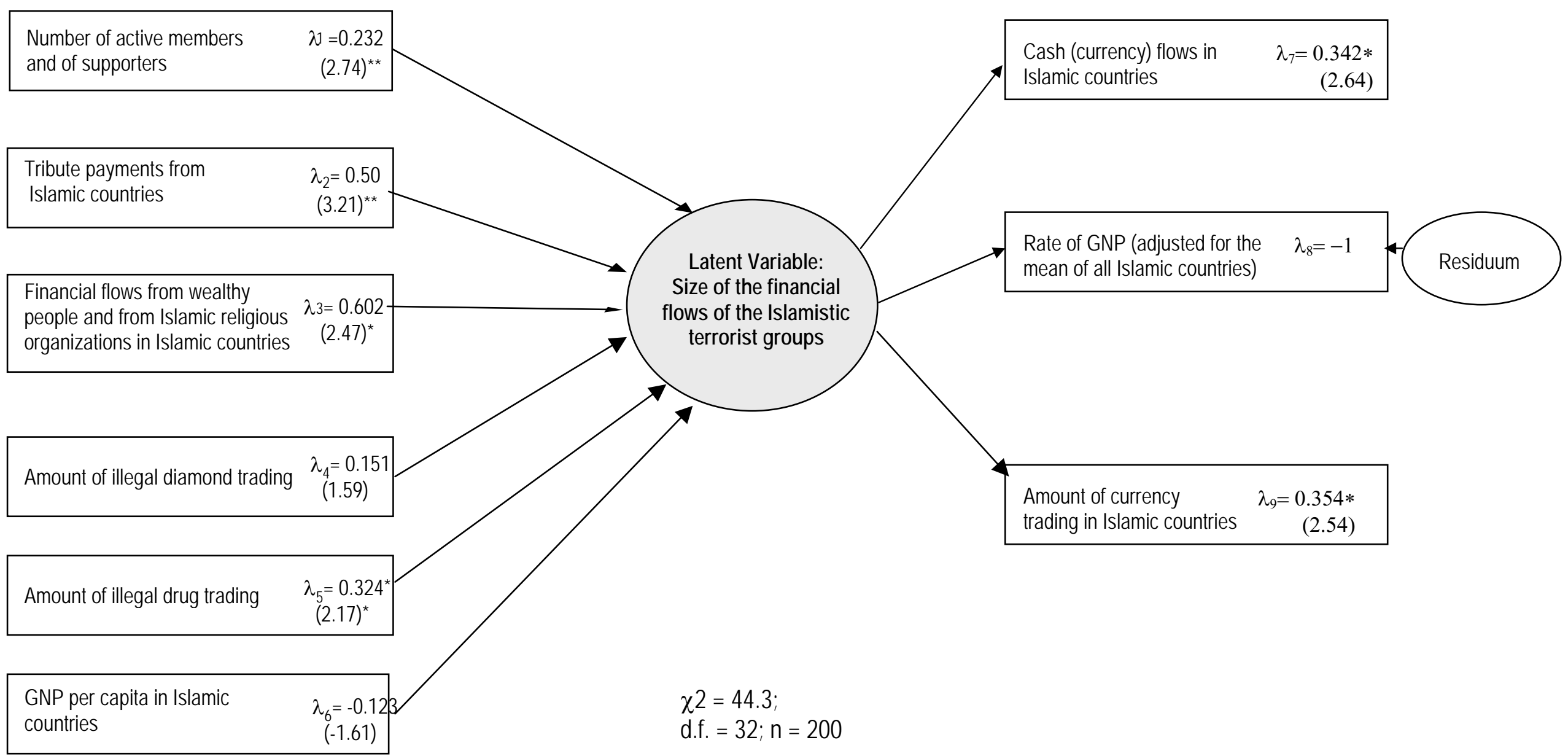


Table 3.1: The Financial Flows and the Kind of Finances of Al-Qaeda and other Terror Organizations

\begin{tabular}{|l|c|}
\hline $\begin{array}{l}\text { Annual financial flows (budget) of Al-Qaeda } \\
\text { (Average 1999-2006) }\end{array}$ & $20-50$ mill. \$ \\
\hline \hline \multicolumn{1}{|c|}{$\begin{array}{l}\text { Ways of financing of terror organisations (using the example of Al- } \\
\text { Qaeda) }\end{array}$} & $30-35 \%$ \\
\hline Drug business (mainly transporting drugs) & $20-30 \%$ \\
\hline Donations from governments or wealthy individuals or religious groups & $15-20 \%$ \\
\hline Tribute payments from Islamic countries & $10-15 \%$ \\
\hline $\begin{array}{l}\text { Number of active members and supporters (including classical crime } \\
\text { activities like kidnapping, blackmail, etc.) }\end{array}$ & $75-100 \%$ \\
\hline SUM & \\
\hline
\end{tabular}

Source: Own calculations.

Table 3.2: $\quad$ Preliminary (Incomplete) Overview of Financial Flows of Arabic Islamic Terror Organizations

\begin{tabular}{|l|c|c|}
\hline \multicolumn{1}{|c|}{ Name } & $\begin{array}{c}\text { Members } \\
\text { (worldwide) } \\
\text { Average over 1999- } \\
2006\end{array}$ & $\begin{array}{c}\text { Current financial flows } \\
\text { (annual budget) }\end{array}$ \\
Average over 1999-2006 \\
\hline Al-Qaeda & $1500-3000$ & 20 -50 mill. \$ \\
\hline Front Islamique du Salut (Algeria) & ca. 400 & ca. 5 mill. \$ \\
\hline Hamas & ca. 2000 & ca. 10 mill. \$ \\
\hline Hizbullah & ca. 10.000 & ca. 50 mill. \$ \\
\hline $\begin{array}{l}\text { Arabic Mujahedin (terror) organisations: } \\
\text { - Irak } \\
\text { - Iran } \\
\text { - Libyan } \\
\text { - Egypt (Egyptian Islamic Jihad; most likely } \\
\text { united with Al-Qaeda; islam./arab.) }\end{array}$ & $\begin{array}{l}\text { ca. } 800 \\
\text { ca. } 600 \\
\text { ca. } 600\end{array}$ & $\begin{array}{c}\text { ca. } 5 \text { mill. \$ } 5 \text { mill. \$ } \\
\text { ca. } 10 \text { mill. \$ } \\
\text { ca. } 8 \text { mill. \$ }\end{array}$ \\
\hline
\end{tabular}

Source: Own calculations. 


\section{Economic Implications and Damages of Transnational Terrorism}

The 9/11 attacks showed that in particular the indirect costs of terrorist attacks are very high. The world GDP dropped by 0.25 percent in 2001/2002 due to the attacks. These losses were spread across all regions of the world and several economic sectors and had long-term consequences for the global economy. ${ }^{17}$

\section{(1) Demand Shock and Heightened Transaction Costs}

The terrorist attacks shook people's mind and trust and lastingly weakened the already fragile consumer confidence in countries across the globe. A reduction in the spending patterns of businesses, private consumers and governments followed. The combination of a demand shock and heightened transaction costs increased in the wake of security and defence policy reactions, further damaging the global economy. ${ }^{18}$ An example of the consequences of a worldwide demand shock was the slump in the stock prices (up to -50 percent) of nearly all air carriers on the American and European stock exchanges after 9/11. ${ }^{19}$

\section{(2) Increased Risks and Insecurity}

Insurance companies reacted to this new form of terrorism with an immediate increase in insurance rates, since potential maximum damages had to be re-evaluated. As a result, contracts were adapted and some reinsurance companies reacted by strongly limiting or ruling out the insurability of damages from terrorist attacks. ${ }^{20}$

\section{(3) Political Implications for the Financial and Money Markets}

Investors adapted their portfolios to new risk structures and the yields of some stocks changed. In many cases terrorist attacks lead to an outflow of capital from the stock markets to more secure investments like gold. Central banks had to react by lowering the rates to support the level of investments. After the 9/11 attacks the Federal Reserve lowered the shortterm interest rates to a 40 -year low of 1.2 percent.

\footnotetext{
17 Many studies have been written on this topic. Some of the most recent ones include: Enders and Sandler (2008), Gaibulloev and Sandler (2008), Abadie (2006), Abadie and Gardezabal (2008), Drakos (2004, 2009a, 2009b) and Frey, Lüchinger and Stutzer (2007).

18 See: Blomberg, Hess and Orphinades (2004), Drakos and Kutan (2003), Gaibulloev and Sandler (2008), as well as Sandler and Enders (2004).

19 See: Chen and Siems (2004), who analysed the reactions of the stock markets after 14 different terrorist attacks and detected highly negative implications.

${ }^{20}$ See: Brown, Cummis, Lewis and Wei (2004), Brück (2004) as well as Li and Schaub (2004).
} 


\section{Summary and Conclusions}

In this paper it is firstly and shortly elaborated how Islamistic terrorist organizations work and how effective they can be. Second and in a much more detailed way a literature review is provided about the finances of terrorist and organized crime organizations, their sources and the various methods they use. Also a short discussion is provided with respect to the interaction of organized crime and terrorist organizations. Then in part 3 with the help of a latend estimate approach it is investigated how large the financial flows of some Islamistic terrorist organizations are and what are their ways of financing. Finally in part 4 some short remarks are made about the economic implications and damages of transnational terrorism, which is really sizeable.

\subsection{Strategies to Tackle the Financing of Terrorism}

On the basis of the results of this paper, a double step strategy is needed to overcome the failings and discrepancies between countries in building a more coordinated global strategy against the financing of terrorism and of organized crime.

In the first step, the states should recognize that they should pay much more attention to the adequate criminalization of terrorist financing, to establish a clear approach towards informal transfer systems, to establish consistent freezing of assets and an approach towards international legal cooperation. This strategy should contain the following aspects / measures:

achieve a common definition of terrorism and a definition of the financing of terrorism;

(2) take into account the increasing global nexus between crime and terror and its negative effect on the global economy;

(3) create a global index of country vulnerability to terrorist financing to improve the capacity of international community to monitor and control key safe havens used by terrorist financiers;

In a second step states / countries should be able to redesign their strategy against terrorism finances taking into account not only previous weaknesses but also a recognisition that one size model does not fit all, especially when there are cash economies and failed states involved. The following points should be taken into account when building up the new strategy: 
(1) The traditional risk-based approach to combat the financing of terrorism must be redefined and newly implemented, because a high number of recommendations from international bodies have created a number of requirements that overlap efforts and undermines efficiency. A high level interagency is needed to harmonize the national efforts on combating of the financing of terrorism.

(2) The policy makers should design a strategy to manage and map different levels of analysis (EU, National and Cross Borders); then they should think about determining the main information requirements how to combat the financing of terrorism.

(3) This change of strategy would compel the international organizations to provide clear policy guidance to the private sector. There is a question of how much information law enforcement agencies should get from financial sector in order to maximize the efficiency of data collection, and thus contribute to keeping financial institutions informed of the new patterns, indicators and typologies relevant to fighting against terrorist financing. The complexity of terrorist financing requires a coordination of public and private sectors, and law enforcement and intelligence agencies need to advice financial institutions on what kind of data they need.

(4) In the case of prosecutions, one of the largest challenges law enforcement faces, is in compiling evidence around a terrorism case. There is a large amount of information that will never be seen in a court room, because it cannot be verified. There is a conflict between collecting evidence for courts (law enforcement) and collecting information to inform government (intelligence agencies).

(5) More and better information exchange is another fundamental component of combating the financing terrorism. There still remain many legal barriers when two or more jurisdictions are involved and when gathering information in one country is a criminal offence if data privacy and bank secrecy laws remain in place. This poses many restrictions on which institutions can disclose data in their possession (compare e.g. SWIFT “case”). The current legal framework of most countries is not designed to deal efficient with the combating the financing of terrorism, because financial institutions must comply with five players: institutions, regulators, law enforcement agencies and society. 


\subsection{General - Strategies for Combating Terrorism ${ }^{21}$}

The threat of terrorism (and organized crime) to the world economy can be countered through the following six politico(-economic) measures: ${ }^{22}$

(1) Combating poverty, especially in countries with fundamentalist religions;

(2) ensuring and strengthening democratic basic rights, freedom of speech, tolerance and openness;

(3) intellectual confrontation of (esp. radical) Islamism; financial support of moderate streams;

(4) law and order measures alone, like the death penalty, do not help since they turn terrorists into martyrers;

(5) complying with human rights when dealing with terrorists and a moderate rhetoric; and

(6) building growth-stimulating institutions in the native regions of terrorists.

\footnotetext{
${ }^{21}$ See Winer (2002), Ware (2004), Kurrild-Klitgaard, Justensen and Klemmensen (2006), Lai (2007), Piazza (2008), Endres and Sandler (2002, 200\&) and Indridason (2008).

${ }^{22}$ Similar recommendations are made by Krueger and Malecková (2003), Li (2005), Piazza (2008a), Abadie (2006), Li (2005), Li and Schaub (2004), Williams (2007) as well as Llussa and Tavares (2008).
} 


\section{References}

Abadie, A. (2006), Poverty, Political Freedom, and the Roots of Terrorism, The American Economic Review, 96(2), pp. 50-56.

Abadie, A. and J. Gardeazabal (2008), Terrorism and the World Economy, European Economic Review, 52/1, pp. 1-27.

Addison, T. and M. Murshed (2005), Transnational Terrorism as a Spillover of Domestic Disputes in Other Countries, Defence and Peace Economics, 16/2, pp. 69-82.

Agarwal, J. D. and Aman Agarwal (2004): Globalization and International Capital Flows, Finance India, Vol. 19/1, pp. 65-99.

Agarwal, J. D. and Aman Agarwal (2006): Money Laudering: New Forms of Crime, and Victimization, paper presented at the National Workshop on New Forms of Crime, Victimization, Department of Criminology, University of Madras, India.

Alexander, D. and Y. Alexander (2002), Terrorism and Business: The Impact of September 11, 2001, Transnational Publishers.

Bagella, Michele, Busato, Francesco and Amedeo Argentiero (2009), Money Laundering in a Microfounded Dynamic Model: Simulations for the U.S. and the EU-15 Economies, Review of Law and Economics, 5/2, 2009, pp. 879-902.

Baker, Raymond W. (2005): Capitalism's Athilles Heel - Dirty Money and How to Renew the Free-Market System, Hoboken, N.J.: John Wiley and Sons.

Bantekas, I. (2003): The International Law of Terrorist Financing, The American Journal of International Law, 97/2, pp. 315-333.

Barth, J., T. Li, et al. (2006): Economic Impacts of Global Terrorism: From Munich to Bali, Capital Series, Milken Institute, pp. 1-38.

Biersteker, T. (2002): Targeting Terrorist Finances: The New Challenges of Financial Market Globalisation, in Worlds in collision. Terror and the Future of Global Order, Palgrave and Macmillan, pp. 74-85.

Blomberg, S. B., G. D. Hess and A. Orphinades (2004), The Macroeconomic Consequences of Terrorism, Journal of Monetary Economics, 51/5, pp. 1007-1032.

Brechner, J. (2007): Un frente extremista cerca de Estados Unidos? Terroristas del Caribe, El Comercio, 18 October, Lima, Peru. 
Brown, J. R., J. D. Cummins, C. M. Lewis and R. Wei (2004), An Empirical Analysis of the Economic Impact of Federal Terrorism Reinsurance, National Bureau of Economic Research, NBER Working Paper 10388, Washington D.C..

Brück, Tilmann (2004), An Economic Analysis of Security Policies, Defence and Peace Economics, 16/5, pp. 375-389.

Bunt, Henk van D. (2007), The Relation between Organized Crime and Informal Markets: The Role of Hawala Bankers in the Transfer of Proceeds from Organized Crime, CRIMPREV, Gant University, Gant, Belgium, Discussion Paper.

Chen, A.H. und T. Siems (2004), The Effects of Terrorism on Global Capital Markets, European Journal of Political Economy, 20/3, pp. 349-366.

Comras, V. (2005): Al Qaeda Finances and Funding to Affiliated Groups, Strategic Insights (Center for Contemporary Conflict), pp. 1-16.

Comras, V. (2007): Al Qaeda Finances and Funding to Affiliated Groups, Terrorism Financing and State Responses, Stanford, pp. 115-133.

Costa, A. M. (2005): Drugs, Crime and Terrorism Financing. Breaking the links, Conference on Combating Terrorist Financing, Vienna, UNODC, pp. 1-7.

Drakos, Kostas (2004), Terrorism - Enclosed Structural Shifts in Financial Risk: Airline Stocks in the Afterperiod of the September $11^{\text {th }}$ Terrror Attacks, Europan Journal of Political Economy, 20/2, pp.435-446.

Drakos, Kostas (2009a), The Determinance of Terrorist Shocks Cross Market Transmission, Economics of Security, Working Paper 17, DIW, Berlin, Economics of Security, September 2009.

Drakos, Kostas (2009b), Cross Country Stockmarket Reactions to Major Terror Events: The Role of Risk Perception, Economics of Security Working Paper 16, DIW Berlin, Economics of Security, September 2009.

Drakos, K., Kutan, A.M. (2003), Regional Effects of Terrorism on Tourism in Three Mediterranean Countries, Journal of Conflict Resolution, 47/5, pp. 621-641.

Eaton, L. (2007): U.S. Prosecution of Muslim Group Ends in Mistrial. New York Times, 23 October, New York.

El Quorchi, M., S.M. Maimbo, et al. (2003): Informal Funds Transfer Systems: an Analysis of the Informal Hawala System, Washington, DC, International Monetary Fund, pp. 1-53. 
Enders, W. and T. Sandler (2002), Patterns of Transnational Terrorism, 1970-1999: Alternative Time-Series Estimates, International Studies Quarterly, 46/2, pp. 145-165.

Enders, W. and T. Sandler (2006), The Political Economy of Terrorism, Cambridge: Cambridge University Press.

Enders, W. and T. Sandler (2008), Economic Consequences of Terrorism in Developed and Developing Countries: An Overview, Terrorism, Economic Development, and Political Openness, P. Keefer and N. Loayza, Cambridge University Press: New York, pp. 17-47.

Ergül, Ergin (2004): Justizministerium, Abteilungsleiter des Direktoriums für Internationales Recht und Auswärtige Beziehungen, Cook, Democracy, January 2004, S. 10 - 13, www.terror.gen.tr/deutsch/artikel.

FATF (2004): Report on Money Laundering and Terrorist Financing, Typologies 2003-2004, Paris.

FATF (2005): Report on Money Laundering and Terrorist Financing, Typologies 2004-2005, Paris.

FATF-GAFI (2005): Third Mutual Evaluation Report on Anti-Money Laundering and Combating the financing of terrorism, Norway: 1-160.

FATF-GAFI (2006): Third Mutual Evaluation Report on Anti-Money Laundering and Combating the financing of terrorism. Portugal: 1-165.

Fischer, Howard, S. (2002), Hawala - What is it and How to Emasculate it, California, Beverly Hills, Study.

FIU: Financial Intelligent Unit des Fürstentums Liechtenstein (2001): Jahresbericht available at www. ilv.li/pdf, , S. 11.

Fletcher, N. and Baldwin, J. (2002), Money Laundery Counter Measures with Primary Focus upon Terrorism and the U.S. Patriot Act 2001, Journal of Money Laundering Control, 6/2, (2002), pp.105-136.

Frey, B. S. and S. Luechinger (2008), Three Strategies to Deal with Terrorism, Economic Papers 27/2, pp. 107-114.

Frey, B. S., S. Luechinger and A. Stutzer (2007), Calculating Tragedy: Assessing the Costs of Terrorism, Journal of Economic Surveys, 21, pp. 1-24.

Freytag, A., J. Krueger, D. Meierrieks and F. Schneider (2009), The Origins of Terrorism: Cross Country Estimates on Socio-Economic Determinants of Terrorism, Discussion Paper, University of Linz, Department of Economics, Linz 2009. 
Fried, E. R., C. L. Schultze, et al. (1975): Higher Oil Prices and the World Economy: the Adjustment Problem, Washington, Brookings Institution 197-226.

Gaibulloev, K., Sandler, T. (2008), Growth Consequences of Terrorism in Western Europe, Kyklos 61/3, pp. 411-424.

Gilmore, W. C. (2004): Dirty money: the Evolution of International Measures to Counter Money Laundering and the Financing of Terrorism, Strasbourg, Council of Europe Pub.

Gilpin, R. (2001): Global Political Economy. Understanding the international Order, Princeton University Press.

Giraldo, J. K. and H. A. Trinkunas (2007): Terrorism financing and state responses: a comparative perspective, Stanford, Calif., Stanford University Press: 1-20, 282-296.

Gross, K., P. R. Brewer and S. Adlay (2009), Confidence in Government and Emotional Responses to Terrorism After September 11, 2001, American Politics Research 37/1, pp. 107-128.

Gunaratna, R. (2003): Inside Al Qaeda: Global Network of Terror. London, Hurst \& Company.

Hutchinson, S. and P. O. Malley (2007): A Crime-Terror Nexus? Thinking on Some of the Links between Terrorism and Criminality, Studies in Conflict \& Terrorism, 30/12, pp. 1095-1107.

IMF (2001): Financial System Abuse, Financial Crime and Money Laundering, Washington, DC, Monetary and Exchange Affairs and Policy Development.

Indridason, I. H. (2008), Does Terrorism Influence Domestic Politics? Coalition Formation and Terrorist Incidents, Journal of Peace Research, 45/2, pp. 241-259.

IWF (1996): Money Laundering and the International Financial System, International Monetary Funds, Fiscal Affairs Department, Washington D.C.

IWF (1998): Money Laundering: The Importance of International Counter Measures, statement by Michael Camdessus at the plenary meeting of the Financial Action Task Force on Money Laundering, Paris.

IWF (2002): Money Laundering: New Facts, Washington (D.C.), 2002

Johnson, J. (2001): In Pursuit of Dirty Money: Identifying Weaknesses in the Global Financial System, Journal of Money Laundering Control, 5/2, pp. 122-133.

Koh, J.-M. (2006): Suppressing terrorist financing and money laundering, Berlin: Springer. 
Kohlmann, E. F. (2006): The Role of Islamic Charities in International Terrorist Recruitment and Financing, DIIS Working Paper, Copenhagen, Danish Institute for International Studies.

Krueger, A.B., Malečková, J. (2003), Education, Poverty and Terrorism: Is There a Causal Connection?, Journal of Economic Perspectives, 17/4, pp. 119-144.

Kurrild-Klitgaard, P., Justensen, M.K., Klemmensen, R. (2006), The Political Economy of Freedom, Democracy and Transnational Terrorism, Public Choice, 128, pp. 289-315.

Labévière, R. (2002): Dollars for Terror. The United States and Islam, New York, Algora Publishing.

Lai, B. (2007), Draining the Swamp: An Empirical Examination of the Production of International Terrorism, 1968-1998, Conflict Management and Peace Science, 24/4, pp. 297-310.

Levi, M. and W. Gilmore (2002b): Terrorist Finance, Money Laundering and the Rise and Rise of Mutual Evaluation: A New Paradigm for Crime Control, in: Financing Terrorism, Netherlands, Kluwer Academic Publishers, pp. 87-115.

Li, Q. (2005), Does Democracy Promote or Reduce Transnational Terrorist Incidents?, Journal of Conflict Resolution, 49/2, pp. 278-297.

Li, Q. and D. Schaub (2004), Economic Globalization and Transnational Terrorism: A Pooled Time-Series Analysis, Journal of Conflict Resolution, 48/2, pp. 230-258.

Llussa, F. and J. Tavares (2008), Economics and Terrorism: What We Know, What We Should Know and the Data We Need, in: Terrorism, Economic Development, and Political Openness, P. Keefer and N. Loayza (editors), Cambridge University Press: Cambridge (Mass.), pp. 233-254.

Luck, E. C. (2005): The Uninvited Challenge: Terrorism Targets the United Nations, in: Multilateralism under Challenge: Power, International Order and Structural Change, Tokyo, United Nations University and the Social Science Research Council, 2005: pp. 336-355.

Makarenko, T. (2002): A Model of Terrorist-Criminal Relations, Jane’s Intelligence Review.

Makarenko, T. (2003a): Tracing the dynamics of the illicit arms trade, Jane's Intelligence Review.

Makarenko, T. (2003b) “A model of terrorist-criminal relations.” Janes’s Intelligence Review. Makarenko, T. (2003) and Sanderson, T.M. (2004). Transnational Terror and Organized Crime: Blurring the Lines. Sais Review, XXIV (1):49-61. 
Masciandaro, D. (2004): Global Financial Crime: Terrorism, Money Laundering and Off Shore Centres, Aldershot, (England), Burlington, Ashgate.

Masciandaro, D. (2005): Financial Supervisory Unification and Financial Intelligence Units, Journal of Money Laundering Control, 8/4, pp. 354-371.

Masciandaro, D. (2006): Offshore Financial Centres and International Soft Laws: Explaining the Regulation Gap, Second Annual Conference: Società Italiana di Diritto ed Economia, Roma, pp. 1-49.

Meter, E. (2003): Providing Global Public Goods: Managing Globalization, Dordrecht: Kluwer, Academic Publisher.

Millard, G. H. (2006): Business of Crime: the Enterprise of Crime and Terror - the Implications for Good Business, Journal of Financial Crime, 13/3, pp. 277-282.

Mintz, J. (1998): Bin Laden’s Finances are Moving Target. The Washington Post, 28 August: A01.

Morigi, A. (2004): Multinazionali del terrore. Alessandria, Piemme, Mimeo.

Mueller, Christoph (1992): Geldwäscherei: Motive - Formen - Abwehr: Eine betriebswirtschaftliche Analyse, St. Gallen.

Napoleoni, L. (2005): Terror Incorporated: Tracing the Dollars behind the Terror Networks, New York, Seven Stories Press.

Newman, E. (2007): Weak States, State Failure and Terrorism, Terrorism and Political Violence, 19/4, pp. 463-488.

Passas, N. (2004): Law Enforcement Challenges in Hawala-related Investigations, Journal of Financial Crime, 12/2: 8.

Peace, F. F. (2007): Foreign policy: The States that Failed us, Washington, etc.: Carnegie Endowment for International Peace, July-August.

Perkel, William (2004), Money Laundering and Terrorism: Informal Value Transfer Systems, American Criminal Law Review, 41/2, pp. 183-211.

Piazza, J.A. (2008), Do Democracy and Free Markets Protect Us From Terrorism?, International Politics, 45, pp. 72-91.

Picarelli, J. (2006): The Turbulent Nexus of Transnational Organised Crime and Terrorism: A Theory of Malevolent International Relations, Global Crime, 7/1, pp. 1-24. 
Picarelli, J. T. and L. I. Shelley (2007): Organised Crime and Terrorism, Terrorism Financing and States Responses: A comparative Perspective. Stanford, Stanford University Press, pp. 39-55.

Pieth, M. (2002): Financing terrorism. Dordrecht, Boston, Kluwer Academic Publishers, vi, $216 \mathrm{p}$.

Razavy, Mark (2005), Hawala: An Underground Haven for Terrorist of Social Phenomenon? Crime, Law and Social Change, Vol. 44/2, pp. 277-299.

Raphaeli, N. (2003): Financing of Terrorism: Sources, Methods and Channels, Journal of Terrorism and Political Violence, 15/4, pp. 59-82.

Reuter, C. (2004), Parasiten des Zorns. Wie Al Khaïda neue Akteure rekrutiert, Internationale Politik, February, pp. 12-20.

Richard, A. C. (2005): Fighting Terrorist Financing: Transatlantic Cooperation and International Institutions, Center for Transatlantic Relations, Johns Hopkins University, 2005.

Rider, B. (2004): The War on Terror and Crime and the Offshore Centres, in: Global Financial Crime: Terrorism, Money Laundering and Offshore Centres, Aldershot, Hants, England, Burlington, VT, Ashgate: pp. 61-95.

Sanderson, T. M. (2004): Transnational Terror and Organized Crime: Blurring the Lines, Sais Review XXIV (1): 49-61.

Sandler, T. and W. Enders (2004), An Economic Perspective on Transnational Terrorism, European Journal of Political Economy, 20/2, pp. 301-316.

Savona, E. U. and ISPAC (Organization) (1997): Responding to money laundering: international perspectives, Amsterdam, The Netherlands, Harwood Academic Publishers.

Schneider, Friedrich (2002a): The Hidden Financial Flows of Islamic Terrorist Organisations: Some Preliminary Results from an Economic Perspective. Discussion Paper, Department of Economics, University of Linz, Austria, presented at „The Economic Consequences of Global Terrorism“, DIW, Berlin, 14. - 15. 6.2002.

Schneider, Friedrich (2002b): Die verborgenen Finanzströme islamistischer Terrororganisationen: Einige vorläufige Erkenntnisse aus volkswirtschaftlicher Sicht. In: Die Friedenswarte/Journal of International Peace and Organization 77/3, S. 293 - 312.

Schneider, Friedrich (2004): The financial flows of Islamic Terrorism, in: Masciandaro, Donato (ed.), Global Financial Crime: Terrorism, Money Laundering and Offshore Centres, Aldershot (Great Britain): Ashgate, 2004, pp.97-126. 
Schneider, Friedrich (2005): Shadow Economies Around the World: What do we Really Know?, European Journal of Political Economy 21/3, pp.598-642.

Schneider, Friedrich (2008a): Turnover of Organized Crime and Money Laundering: Some Preliminary Empirical Findings, Discussion Paper, Department of Economics, University of Linz.

Schneider, Friedrich (2008b): Money Laundering from Revenues from Organized Crime: Some Preliminary Empirical Findings, revised version of a paper which was presented at the Conference „Illicit Trade and Globalization“, CES-ifo Venice Summer Workshop, Venice National University, San Servolo, July 14-15, 2008.

Schneider, Friedrich (2009): Die Finanzströme von Organisierter Kriminalität und Terrorismus: Was wissen wir (nicht)?, Vierteljahreshefte zur Wirtschaftsforschung, DIW Berlin, 78/4, pp. 73-87.

Schneider, Friedrich and Enste, Dominik (2000), Shadow Economy: Causes, Size and Consequences, Journal of Economic Literature, Vol. 38/1 (March 2000), pp. 77-114.

Schneider, Friedrich, Dreer, Elisabeth und Wolfgang Riegler (2006): Geldwäsche: Formen, Akteure, Größenordnung - Warum die Politik machtlos ist, Wiesbaden: Gabler-Verlag.

Schneider, Friedrich und Windischbauer, Ursula (2008): Money Laundering: Some Facts, European Journal of Law and Economics, 26/4, pp.387-404.

Schneider, Friedrich, Tilman Brück und Daniel Meierrieks (2010): The Economics of Terrorism and Counterterrorism: A Survey, Discussion Paper, DIW Berlin, Germany, and Department of Economics, Johannes Kepler University Linz, Austria.

Sedgwick, M. (2007): Inspiration and the Origins of Global Waves of Terrorism, Studies in Conflict \& Terrorism, 30: 97-112.

Shahar, Y. (2001): Tracing Bin Laden’s money: Easier said than done, Israel, www.ict.org.

Shelley, L. (2005): The Nexus between Terrorism and Organized Crime, in: Confronting Terrorism Financing, Lanham, MD (etc.): University Press of America, pp. 29-33.

Simpson, G. (2007a): U.S. Tracks Saudi Bank Favored by Extremists. The Wall Street Journal, 26 July, New York: A10.

Simpson, G. (2007b): U.S. Investigating Firm Tied to Muslim Investors. The Wall Street Journal, January 31, pp. 1-2.

Siska, Josef (1999): Die Geldwäscherei und ihre Bekämpfung in Österreich, Deutschland und der Schweiz, Wien: Linde-Verlag. 
Smillie et al (2000). The Heart of the Matter: Sierra Leone, Diamonds and Human Security.

Canada: Ontario, Partnership Africa.

Takats, Ilöd (2007): A Theory of "Crying Wolf": The Economics of Money Laundering Enforcement, Paper presented at the Conference "Tackling Money Laundering", University of Utrecht, Utrecht (The Netherlands), November 2-3, 2007.

Tavares, J. (2004), The Open Society Assesses its Enemies: Shocks, Disasters and Terrorist Attacks, Journal of Monetary Economics, 51/5, pp. 1039-1070.

Truman, E.M. and Peter Reuter (2004), Chasing Dirty Money: Progress on Anti-Money Laundering, Institute for International Economics, United States: Washington, November 2004.

UNO (2004): World Drug Report, United Nations Office for Drug and Crime Prevention (UDCCP), Oxford-New York.

UNO (2005): World Drug Report, United Nations Office for Drug and Crime Prevention (UDCCP), Oxford-New York.

US-Defence Department (1996): Patterns of Global Terrorism 1996, from http://www.state.gov/www/global/terrorism/1996Report/overview.html.

Walker, John (2000): Money Laundering: Quantifying International Patterns, Australian Social Monitor, 2/6, pp.139-147.

Walker, John (2004): A Very Temptative Exploration of the Relationship between Shadow Economy and the Production and Transit of Illicit Drugs, New York: UNODC document.

Walker, John (2007): Measuring Global Money Laundering, Paper presented at the conference “Tackling Money Laundering”, University of Utrecht, Netherlands.

Walker, John and Brigitte Unger (2009), Measuring Global Money Laundering: The Walker Gravity Model, Review of Law and Economics, 5/2, p. 821-853, DOI: 10.2202/15555879.1418.

Ware, M. (2004): Responding to Terrorism and Achieving Stability in the Global Financial System: Rational Policy or Crisis Reaction, Journal of Financial Crime, 11/4, pp. 380397.

Wilkinson, P. (2005): International Terrorism: The Changing Threat and the EU's Response, Cahier de Chaillot 84.

Zdanowicz, John (2009), Trade-Based Money Laundering and Terrorist Financing, Review of Law and Economics, 5/2, p.854-878. 
Williams, P. (2007): Warming Indicators and Terrorist Finances, Terrorism financing and state responses: a comparative perspective, Stanford, Calif., Stanford University Press: 72-92.

Wilton Park Report (2007): Combating Financing of Terrorism, Conference WP852.

Winer, J. (2002): Globalization, Terrorist Finance, and Global Conflict-Time for a White List? Financing terrorism, Dordrecht and Boston: Kluwer Academic Publisher, pp. 5-40.

Yepes, Verdugo (2008): International Cooperation in the Fight against Terrorist Financing, Dissertation, 2008, Universitat de Barcelona, Barcelona, Spain. 